\title{
A GRAPHIC COMPARISON OF THE ALTERATION OF ROCKS BY WEATHERING WITH THEIR ALTERATION BY HOT SOLUTIONS.
}

\author{
Edward Steidtmann.
}

\section{CONTENTS.}

Introduction.

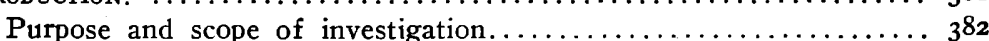

Alteration. of Rocks by Hot Solutions....................... $3^{83}$

The Clifton-Morenci monzonite porphyries.................. $3^{84}$

Method of graphic comparison of chemical and mineralogical

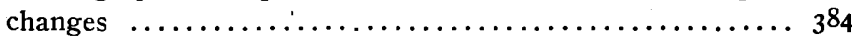

Chemical changes of the Clifton-Morenci monzonite porphyries.. 385

I. The amount of gain or loss of individual constituents assuming rock mass constant.................. $3^{86}$

2. Gain or loss in rock mass assuming any one constituent

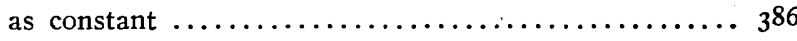

3. Gain or loss of individual constituents assuming any one constituent as having remained constant........... $3^{87}$

Mineralogical changes involved in the alteration of the CliftonMorenci monzonite porphyries................... 393

Composite of acid igneous rocks altered by hot solutions......... 394

Chemical changes ................................. 394

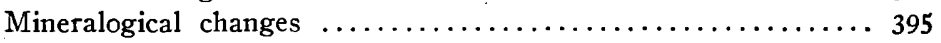

Summary ...................................... 397

Alteration of Rocks by Weathering...................... 399

Method of obtaining average compositions of the weathered rocks.... 399

Chemical changes in the weathering of an acid igneous rock....... 40I

Chemical changes in the weathering of basic igneous rocks........ 402

Mineralogical changes in the weathering of acid and basic igneous

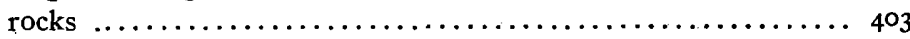

The relation of the ratio: $\frac{\text { bases }}{\text { combined silica }}$ to the ratio: $\frac{\text { bases lost }}{\text { silica } \cdots 404}$

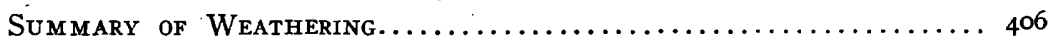

Comparison of Weathering and Thermal Alteration........... 407

\section{INTRODUCTION.}

Hot ore-bearing solutions have been very generally appealed to of recent years as the chief factor in the genesis of the larger 
number of metalliferous deposits. Any information that will tend to throw light on the nature of such solutions, the processes by which they have operated and the work which they have accomplished may be expected to materially aid our knowledge of ore-genesis.

The writer has endeavored in the following pages to approach the problem by a graphic comparison of the chemical and mineralogical changes involved in the alteration of rocks by weathering with the changes of the same kinds of rocks effected by the presumably hot solutions on similar rocks adjacent to metalliferous veins. In both cases chemical and microscopical analyses of the original and altered rocks form the basis of comparison.

The processes, agents and results of weathering may be subjected to direct observation and measurement. Our knowledge of weathering, it is true, is far from complete, but still observations are sufficiently numerous to warrant the hope that the nature and work of weathering solutions may be placed upon a quantitative basis. Far less is known regarding the agents, processes and results of thermal solutions. Thermal solutions are active through wide ranges of temperature and pressure. from the hot springs, which issuing at the surface cause certain observable alterations under atmospheric pressure, to aqueous and pneumatolytic solutions, which effect alterations in the depths of the earth under conditions of temperature and pressure which are unknown.

The data at hand regarding the alteration of rocks by hot springs is relatively scanty. Direct observations of the physical and chemical conditions of solutions active in the depths of the earth is impossible. The results of the action of thermal solutions at depth become known only after erosive processes have exposed the regions where they have long since ceased to be active under the same conditions of temperature and pressure, if active at all. From these observed results certain inferences have been drawn as to the agents and the processes which have produced them.

Thus in the Clifton-Morenci district, the thermal solutions have effected a concentration of silica, and various salts, among 
them the heavy metals, but have developed almost no carbonates. Lindgren ${ }^{1}$ concludes that therefore the solutions themselves were rich in silica and the heavy metals and entirely deficient in carbonic acid.

In this paper an attempt is made to attack the question of the nature of thermal solutions at depth from a new standpoint. The fairly well-known results of weathering are to be used as a standard of measurement against which to gauge the less wellknown and more obscure results of the work of thermal solutions with the hope that such a comparison may bring about a clearer understanding of the nature of thermal solutions.

An acknowledgment of the most important bibliographic sources of the data on which this comparison is based will be found at the end of this discussion. The conclusions of Lindgren, Spurr and others regarding the thermal nature of the solutions which have caused certain alterations of the wall rocks adjacent to ore bearing veins are accepted. The mineral compositions given have largely been computed from chemical analyses and mineral descriptions, although some were taken from the cited bibliography. The data available have warranted a comparison of the thermal alterations and weathering of the acid igneous rocks only.

\section{THE ALTERATION OF ROCKS BY HOT SOLUTIONS.}

The alterations of the Clifton-Morenci porphyries described by Lindgren in professional paper 43 have been selected as a type of this form of metamorphism. These will be followed by a composite of a series of thermally altered acid igneous rocks. It is to be admitted that any one of the rocks described as thermally altered, may have suffered more or less subsequent modification by weathering. Whether or not this is true, they exhibit certain characteristics which are not produced by simple weathering.

1 "The Copper Deposits of the Clifton-Morenci District, Arizona," by W. Lindgren, Professional Paper No. 43, U. S. Geol. Sur. 
THE CLIFTON-MORENCI MONZONITE PORPHYRIES.

The fresh Clifton-Morenci monzonite porphyries consist of a fine-grained micro-crystalline groundmass of quartz and orthoclase, and accessory amounts of apatite, titanic iron and zircon. Phenocrysts of biotite, albite, oligoclase, orthoclase and quartz are present.

The altered rocks are generally composed of a dense light colored mass of quartz, sericite, sulphides, chlorite, serpentine and accessory minerals. In comparing the fresh rock pound for pound with the altered rock, the chemical changes consist essentially in a loss of all constituents excepting silica, sulphides, potash and water.

\section{Method of Graphic Comparison of Chemical and Mineralogical Changes.}

The percentage weights of the chemical and mineralogical constituents of the fresh and altered rocks have been platted as sectors of equal circles. (See Diagrams Nos. I., II.) Alteration may increase certain constituents, leave some unchanged. remove others entirely and introduce new ones in their place. Complete removal of a constituent is represented by a radial arrow projecting from the center of the diagram of the altered rock. By changing the arcs and radii of the sectors representing the composition of the original rock so that the angles subtended by their arcs are equal to the angles subtended by the arcs of the corresponding sectors of the altered rock, and then superimposing the former upon the latter, a perspective of the relative gains and losses of the various constituents can be obtained. Under these conditions the radii of the sectors representing the chemical or mineralogical components are proportional to the square roots of their respective percentage weights. Assuming rock mass constant, then the constituents whose superimposed arcs fall outside of the original circle have suffered loss in proportion to the difference between the areas of their sectors. On the other hand if the arc of a superimposed constituent falls inside the original circle, it follows that the constituent has gained in proportion to 
the difference of the areas of the respective sectors representing this constituent in the fresh and altered rock.

The circular diagrams have the further advantage of showing at a glance which of the constituents have lost or gained when any one constituent is assumed to have remained constant. The constituents whose superimposed arcs fall outside of the superimposed constituent assumed as constant have suffered loss, while those which lie inside have gained.

Knowing the volume change of the rock even qualitatively, the positions of the various superimposed arcs with respect to the original circle are an index of the relative degree of constancy of the various constituents.

The percentage values of the sectors of each constituent in the fresh rock as compared with the corresponding sector in the altered rock are given with the tables of analyses.

Chemical Changes of the Clifton-Morenci Monzonite Porphyries.

If a measure of the chemical and mineralogical changes involved in the alteration of the Clifton-Morenci monzonite porphyries is desired, the chemical and mineralogical components of the fresh and altered rocks could easily be platted as sectors of the circular diagrams. Thus silica 68.04 per cent. in the fresh rock No. I. in Table I., page 387 , can be platted as a sector whose area is 68.04 per cent. of the area of a circular diagram, and similarly the silica of the altered rock No. III., Table I., can be platted as a sector whose area is 69.55 per cent. of the total area of the circular diagram. By changing the arc and radius of the silica sector of No. I. so that the arc of No. I. subtends the same angle as the arc of No. III., and then superimposing the silica sector of No. I. upon the silica sector of No. III., it is found that the arc of the superimposed silica sector falls inside of the circumference of the circle. The sectors of all the other constituents of the fresh rock can be changed in a similar manner and superimposed upon the corresponding sectors of the altered rock. This is done in Diagram I. From Diagram I., it is possible to estimate directly (I) the amount of gain or loss of each con- 
stituent assuming rock mass constant (2) the amount of gain or loss in rock weight assuming any one constituent as constant, and (3) the gain or loss of individual constituents assuming any one constituent as constant.

I. The Amount of Gain or Loss of Individual Constituents Assuming Rock Mass Constant.-By the assumption of constancy of rock mass it is meant that one hundred pounds of the fresh rock will weigh exactly one hundred pounds when altered. One hundred pounds of fresh Clifton Morenci monzonite porphyry contain 68.04 pounds of silica, while the altered rock No. 3 contains 69.55 pounds. The weight of silica in No. I. is 98 per cent. of the weight of silica in the altered rock; that is, an addition of 2 per cent. of silica has taken place. This increase can be read directly from Diagram I. The silica arc of No. I. delimits 98 per cent. of the silica sector of No. III.

Similarly the iron sulphide arc of the original rock delimits 7.7 per cent. of the iron sulphide sector of No. III., the altered rock.

The potash aŕc of No. I. delimits 77.7 per cent. of the potash sector of the altered rock No. III. in Diagram I., therefore potash has gained $3^{2}$ per cent. of its own weight.

In the same diagram, the copper sulphide arc of the fresh rock delimits 28.6 per cent. of the copper sulphide sector of the altered rock, No. III.

The soda arc of the fresh rock in Diagram I. is seen to delimit 3,I30 per cent. of the soda sector of No. III. It follows that the loss of soda is $(3,130-100) / 3130$, or 98 per cent. of its original weight.

The lime arc of the fresh rock is I,470 per cent. of the lime sector of the altered rock No. III. in diagram I., therefore the loss of lime amounts to (1470- IOO)/1470, or 93 per cent. of the original lime content.

It is important to keep in mind that the above conclusions hold only under the assumption of constancy of rock mass.

2. Gain or Loss in Rock Mass Assuming any one Constituent as Constant.-In Diagram I., it has been seen that the arc of the potash sector of the fresh rock includes only 77.7 per cent. 
TABLE I

Chemical Composition of Fresh and Altered Monzonite Porphyry, Clifton-Morenci District. (Lindgren, Prof. Paper 43, U. S. Geological Survey, pp. I67-168.)

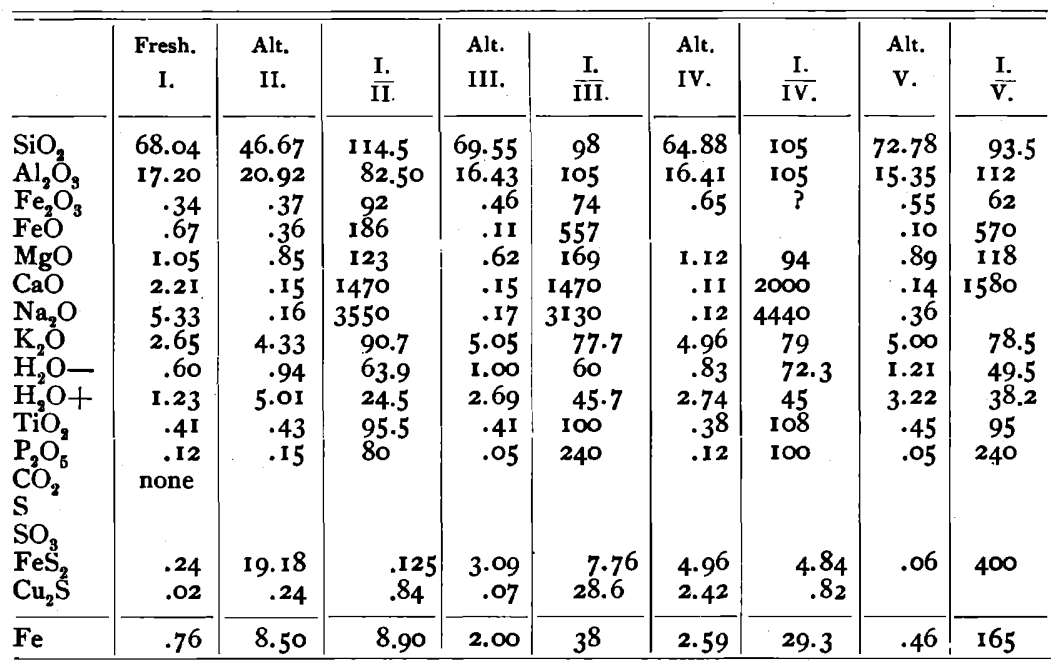

of the area of the potash sector of the altered rock, No. III. If potash has remained constant, it would mean that 77.7 pounds of the altered rock contains as much potash as one hundred pounds of fresh rock, and that the altered rock has lost 32.3 pounds of constituents other than potash per one hundred pounds of fresh rock.

If lime is assumed to have remained constant in Diagram I., it would follow that the rock mass had received an addition of I,370 pounds of materials other than lime per Ioo pounds of fresh rock. The lime arc of the lime sector of the fresh rock includes 1,470 per cent. of the area of the lime sector of the altered rock; that is, Ioo pounds of fresh rock contain as much lime as I,470 pounds of the altered rock, consequently the assumption of lime constancy involves an addition of 1,370 pounds of materials per hundred pounds of fresh rock.

3. Gain or Loss of Individual Constituents Assuming any one Constituent as having Remained Constant.-It has been stated that Ioo pounds of fresh rock contain as much potash as 
77.7 pounds of the altered rock in Diagram I., and that 100 pounds of altered rock contain 69.55 pounds of silica. Assuming potash constant Ioo pounds of fresh rock on altering to No. III. would contain only 77.7 per cent. of 69.55 pounds, or 54 pounds of silica. The silica loss involved in the process of alteration is $68.04-54$, or 14 pounds of silica per one hundred

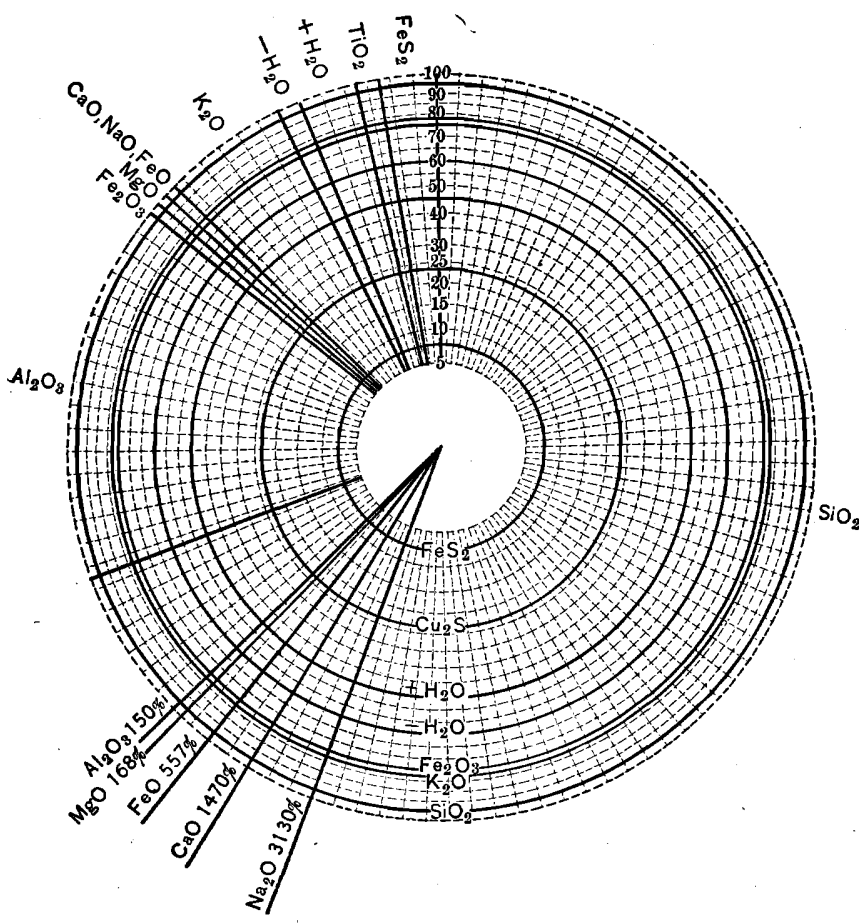

Fig. 29. Diagram I. Chemical composition diagram of the fresh CliftonMorenci porphyry No. I. and the thermally altered phase No. III.

pounds of fresh rock. The percentage loss of silica with potash constant is therefore $14 / 68.04$, or 20.3 per cent. of its original weight.

For clearness, the above problem is given a brief mathematical statement.

Silica in roo pounds of fresh rock equals 68.04 pounds.

IOO pounds of fresh rock alters to 77.7 pounds of altered rock No. III. 
77.7 pounds of altered rock contain 54 pounds of silica.

The silica loss per roo pounds of fresh rock is $69.55-54$ or I4 pounds.

The loss per cent. in silica is $68-54 / 68$, or 20.3 per cent.

Diagram I. shows that Ioo pounds of fresh rock contain as much silica as 98 pounds of altered rock. The silica in one hun-

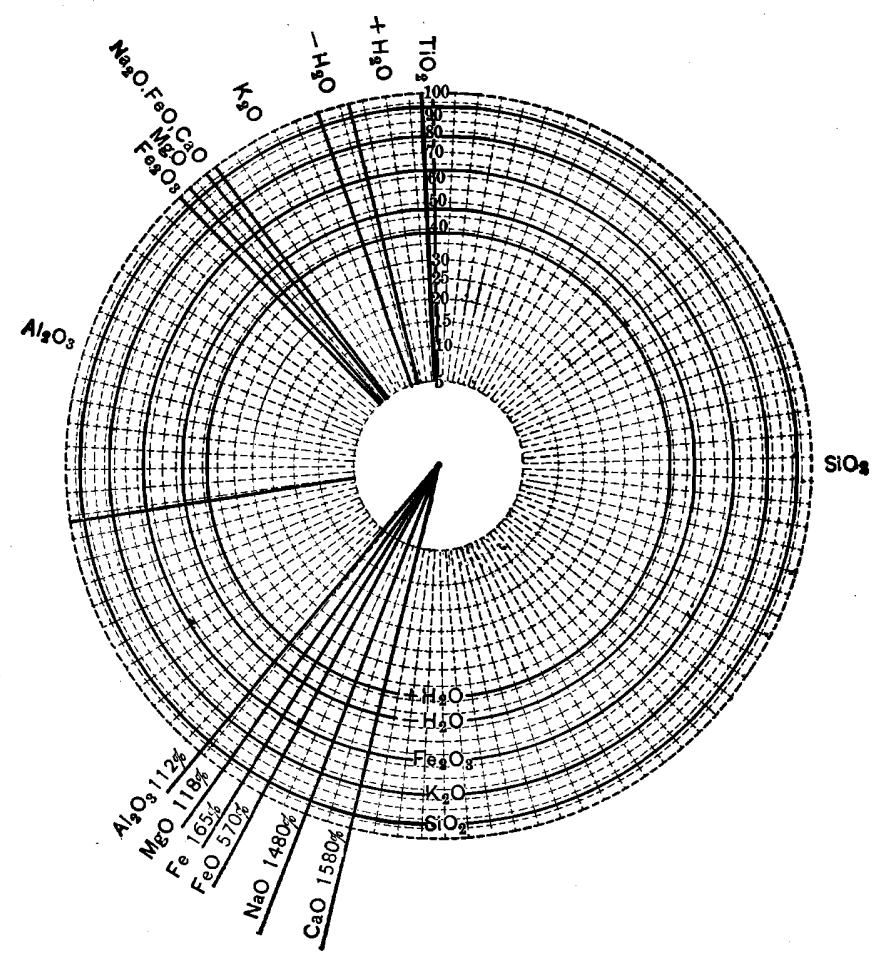

Fig. 3o. Diagram II. Chemical composition diagram of the fresh CliftonMorenci porphyry No. I. and the thermally altered phase No. V.

dred pounds of fresh rock can be stated 98 per cent. of 69.55 . Assuming potash constant the weight of silica in the altered rock resulting from the alteration of 100 pounds of fresh rock can be expressed as 77.7 per cent. of 69.55 .

The following statement can be made of the problem of silica loss with potash constant. 
Pounds of silica in Ioo pounds of fresh rock equals 98 per cent. of 69.55 .

Pounds of silica in the altered rock resulting from the alteration of IOO pounds of fresh rock equals 77.7 per cent of 69.55 .

The loss of silica involved in the alteration of 100 pounds of fresh rock assuming potash constant is ( 98 per cent. 69.55) - (77.7 per cent. 69.04).

The loss per cent. of silica per Ioo pounds of fresh rock assuming potash constant is $\frac{(98 \text { per cent. } 69.55)-(77.7 \text { per cent. } 69.55)}{(98 \text { per cent. } 69.55)}=$

$$
\frac{98-77.7}{98}=20.3 \text { per cent. }
$$

The above demonstration points out a simple method of determining the percentage gain or loss of any constituent when any one constituent is assumed constant. 98 is the percentage intercept of the silica arc of the fresh rock in Diagram I., and 77.7 is the intercept of the potash arc of the fresh rock in the same diagram. The following simple rule can therefore be formulated: For determining the percentage gain or loss of any one constituent when some other constituent is assumed to have remained constant. Take the difference of the percentage intercepts of the arcs of the respective constituents, and divide by the intercept of the arc of the constituent whose gain or loss per cent. is to be determined.

Following this general interpretation of the chemical changes expressed by the circular diagrams, a brief résumé is given of the chemical and mineralogical changes involved in the alteration of the Clifton-Morenci wall rocks adjacent to ore-bearing veins. The same general interpretation applies to the mineralogical changes expressed by the diagram as for the chemical changes.

I. Assuming rock mass constant, the altered rock No. III., Diagram I. has lost soda, lime, ferrous iron, magnesia, and alumina in the order mentioned. Silica, potash, ferric iron, both free and combined water, copper sulphide and iron sulphide 
have gained, the latter showing the largest gain and silica the least.

In rock No. V., Diagram II., which marks an extreme stage of alteration, the same assumption involves a loss of lime, soda, ferrous iron, magnesia, alumina and an increase of silica potash,

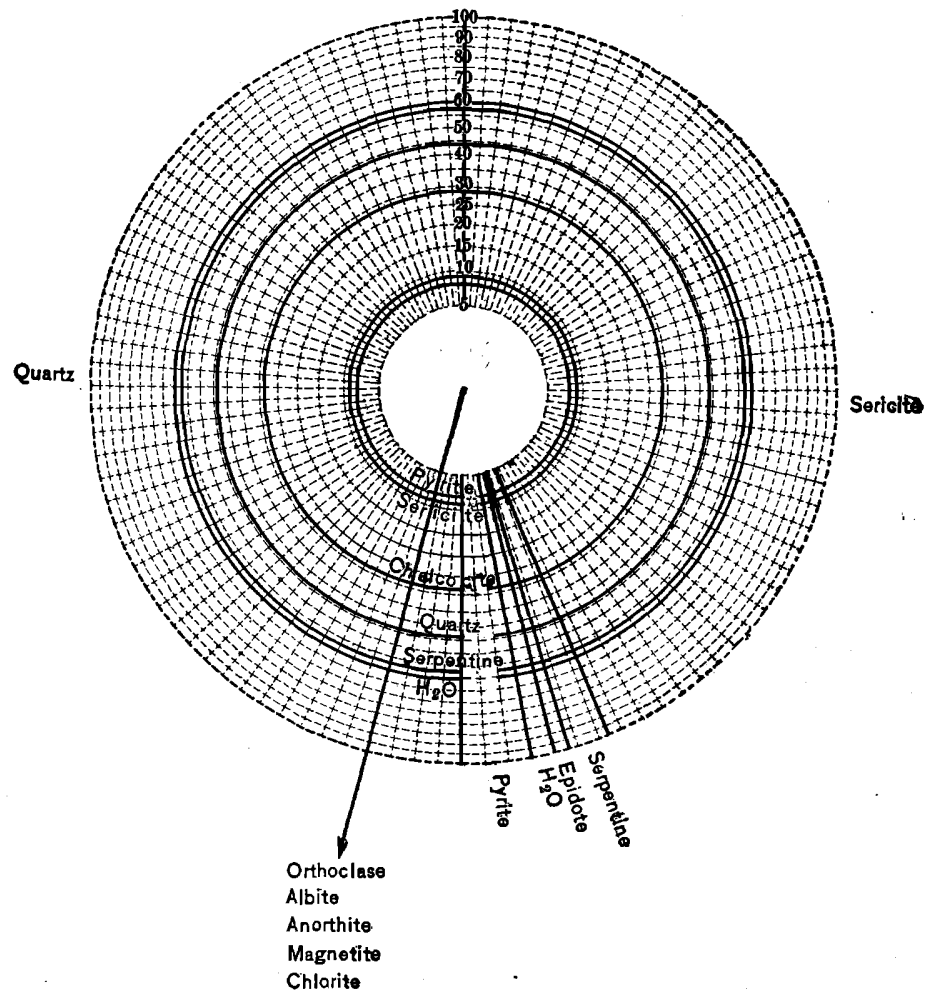

Fig. 3I. Diagram III. Mineral composition of the fresh Clifton-Morenci monzonite porphyry and the altered rock No. III.

ferric iron and both free and combined water. Lime is the most soluble, and water has received the largest increase.

2. Under the assumption that either silica, potash, ferric iron, both free and combined water, copper sulphide and iron sulhpide are constant the alteration of rock No. III. involves loss of material per unit volume of fresh rock. On the other hand assuming alumina, magnesia, ferrous iron, lime or soda 
constant would involve a considerable gain in weight per unit volume of fresh rock. The altered rock is slightly more porous than the fresh rock, and the mineral specific gravity of the altered rock is higher than that of the fresh rock when the increase in sulphides is considerable as in Rock No. III. The conclusion is therefore warranted that both introduction and loss of materials has taken place.

Diagram II. shows the same general relation as Diagram I.

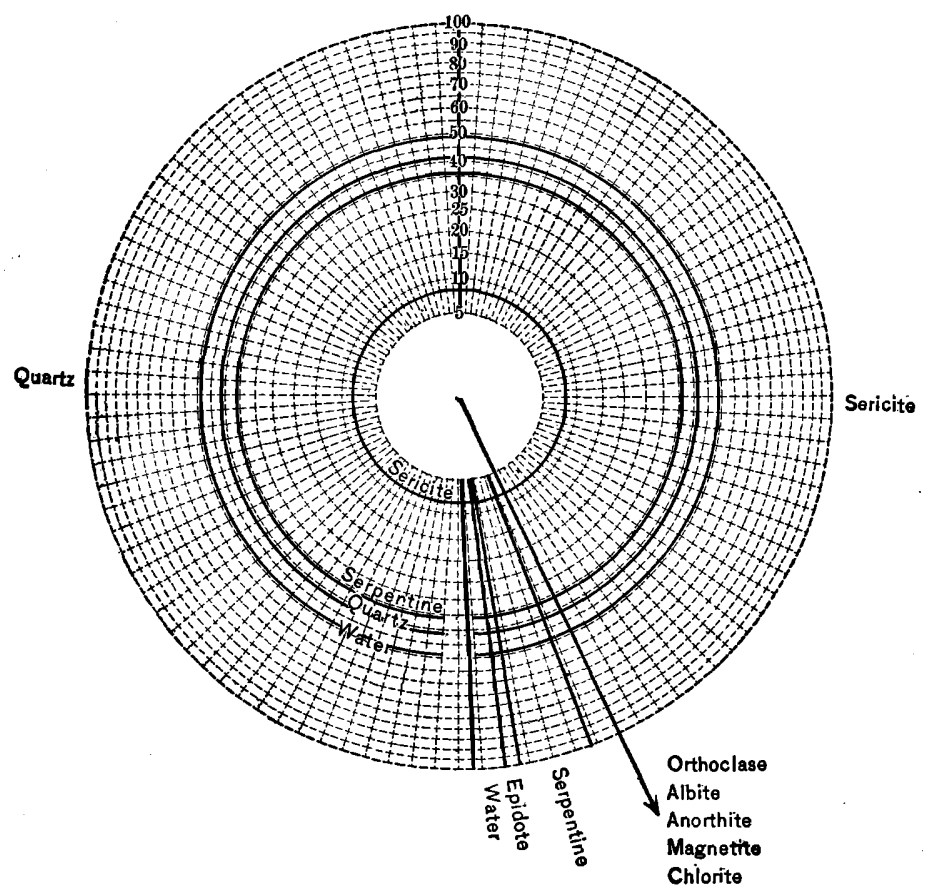

Fig. 32. Diagram IV. Mineral composition of the fresh and altered Clifton-Morenci monzonite porphyry No. V.

only that in the extreme stage of alteration, silicification is more important than the increase in sulphides.

3. Assuming silica constant in Diagrams I. and II. would involve gain in potash, ferric iron, both combined and free water, and a loss of alumina, magnesia, ferrous iron, lime and soda. Diagram I. shows a large increase in sulphides. The assump- 
tion of constancy for potash indicates loss of silica and a gain or loss of all other constituents in the same order as under silica constant. Finally if the sulphides are regarded as constant in Diagram I., all the other constituents have suffered loss.

\section{Mineralogical Changes of the Clifton-Morenci Monzonite Porphyries.}

The mineralogical changes expressed by the diagrams are decomposition of the feldspars, magnetite, ilmenite and chlorite. The titanium dioxide of ilmenite assumes the form of rutile; the potash orthoclase becomes a part of the secondary sericite, and magnetite alters to pyrite. Serpentine takes up the magnesia in the altered rock and is secondary after the chlorite which in turn is a product of decomposition. Kaolin does not appear to be a thermal alteration product and this accounts for the decrease in alumina. As soon as the bases have been removed to such an extent that all the aluminium cannot enter into combination as a baso-alumino silicate, its removal becomes necessary, since it

TABLE II.

Mineral Content of Fresh and Altered Clifton-Morenci Monzonite PORPHYRIES.

\begin{tabular}{|c|c|c|c|c|c|c|c|c|c|}
\hline & I. & II. & $\frac{\text { I. }}{\text { II. }}$ & III. & $\frac{\text { I. }}{\text { III. }}$ & IV. & $\frac{\text { I. }}{\text { IV. }}$ & v. & $\frac{\mathbf{I}:}{\mathrm{V} .}$ \\
\hline $\begin{array}{l}\text { Orthoclase ........... } \\
\text { Albite }\end{array}$ & $\begin{array}{l}13.12 \\
45.26\end{array}$ & & & & & & & & \\
\hline Anorthite................. & 9.52 & & & & & & & & \\
\hline $\begin{array}{l}\text { Apatite.................................. } \\
\text { Zircon...... }\end{array}$ & .28 & .36 & 78 & .12 & 233 & .30 & .93 & .12 & 233 \\
\hline 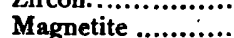 & .02 & & & & & & & & \\
\hline Ilmen & $.8 \mathbf{I}$ & & & & & & & & \\
\hline $\begin{array}{l}\text { Rutile. } \\
\text { Sericite.......................... }\end{array}$ & & 2.43 & & $.4 I$ & & .38 & & .45 & \\
\hline Kaolin ....... & 3.75 & $\begin{array}{l}38.50 \\
17.90\end{array}$ & $9 \cdot 75$ & $43 \cdot 44$ & 8.65 & 44.94 & 8.35 & 44.29 & 8.40 \\
\hline $\begin{array}{l}\text { Chlorite ................... } \\
\text { Serpentine................ }\end{array}$ & $\begin{array}{r}3.04 \\
.98\end{array}$ & 2.81 & 148 & & & & & & \\
\hline Epidote...... & $\begin{array}{l}.90 \\
.59\end{array}$ & 2.01 & 34.0 & $\begin{array}{r}1.71 \\
.43\end{array}$ & 57 & 2.74 & 35.8 & $\begin{array}{l}2.71 \\
.36\end{array}$ & 36 \\
\hline Alunite...................... & & .46 & & .26 & & 26. & & $.2 \mathrm{I}$ & \\
\hline Wate & .60 & .94 & 64.4 & $1 . \infty$ & 60 & 83. & .72 & I.2I & 49.5 \\
\hline .................... & .24 & 19.18 & .125 & 3.09 & 7.8 & 4.96 & 4.85 & .06 & 400 \\
\hline Chalco & .02 & .24 & & .07 & 28.6 & 2.42 & .32 & & \\
\hline Sphale & .03 & $\begin{array}{r}.32 \\
.20\end{array}$ & & & & & & & \\
\hline Quartz .................... & 21.35 & 19.13 & IIo & 49.33 & 42.8 & 43.03 & 49.00 & $50.8 \mathrm{I}$ & 41.50 \\
\hline
\end{tabular}

Mineral analysis by Lindgren. 
apparently cannot assume any other stable form. Kaolinic veins appear in No. II., but these do not contain pyrite. Since pyrite, sericite and quartz constitute an intimate mixture in the altered rock, indicating contemporaneous processes, the absence of pyrite in the kaolinic veins leads to the inference that their genesis is different from that of the altered, adjacent country rock.

Kaolin is an abundant alteration product of vadose solutions, and therefore the evidence is strong in favor of the superposition of kaolin upon earlier thermal alteration products by processes of weathering.

COMPOSITE OF ACID IGNEOUS ROCKS ALTERED BY HOT SOLUTIONS.

The Clifton-Morenci monzonite porphyries have furnished a type of rock alteration by hot solutions. Attention is now directed to the study of composites made up from eight analyses of fresh acid igneous rocks, and seventeen analyses of thermally altered acid igneous rocks from the Tonopah, Clifton-Morenci, Bingham, Willow Creek, Pilbara and Cripple Creek districts. Tables III. and IV. give the chemical and mineralogical compositions of the composite fresh and altered rocks, and diagrams V. and VI. present a graphic illustration of the chemical and mineralogical changes.

Chemical Changes.-On comparing diagram V. representing the chemical changes involved by the alteration of the composite acid igneous rocks by hot solutions with diagrams I and II. representing the changes which the Clifton-Morenci monzonite porphyries have undergone, it is observed that the changes in both cases are essentially the same. The superimposed constituents whose arcs fall within the circle are essentially the same in both cases. It necessarily follows that the superimposed constituents whose arcs fall outside the circle are also the same in both cases. The arcs of the superimposed constituents, while bearing a relatively constant relation to the circumference of the circle, do not bear a constant relation to each other. They change their position with respect to each other. It is there- 
fore evident that the alteration of rocks by thermal solutions lacks rigid uniformity. Certain constituents are, however uniformly concentrated; that is, the arcs of their superimposed sectors persistently appear on the inside of the circular diagram. Other constituents are persistently unstable; that is the arcs of their superimposed sectors uniformly appear on the outside of the circle. The relative rates with which the various constitu-

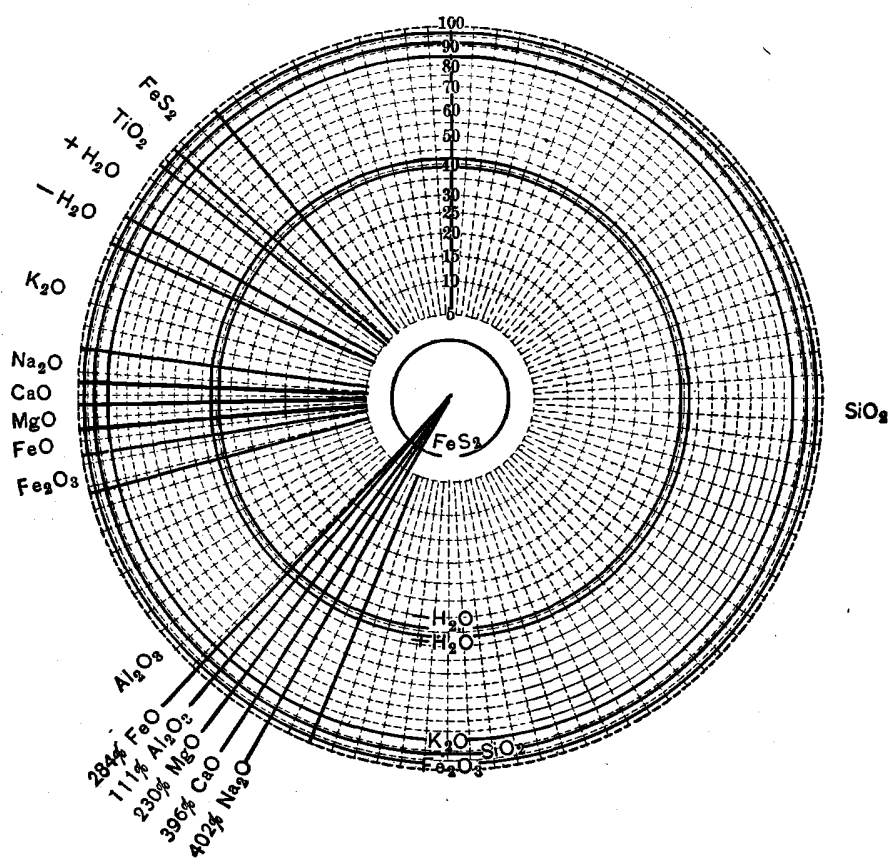

Fig. 33. Diagram V. Diagram illustrating the chemical changes involved in the alteration of an average acid igneous rock by thermal solutions.

ents are concentrated or eliminated is variable, and therefore the arcs delimiting the superimposed sectors shift their position with respect to each other.

Since the chemical changes of the composite acid igneous rock altered by hot solutions are essentially the same as in the CliftonMorenci district, it is needless to repeat in detail the nature of these changes.

Mineralogical Changes.-The mineralogical changes of the 
composite acid igneous rocks effected by hot solutions, like the chemical changes are in essential agreement with mineralogical changes of the Clifton-Morenci porphyries, as will be seen by a comparison of diagrams III. and IV. with diagram VI. Magnetite and the original ferromagnesian silicates are rapidly decomposed. The plagioclase feldspars are more or less decomposed depending upon the degree of alteration. Orthoclase is

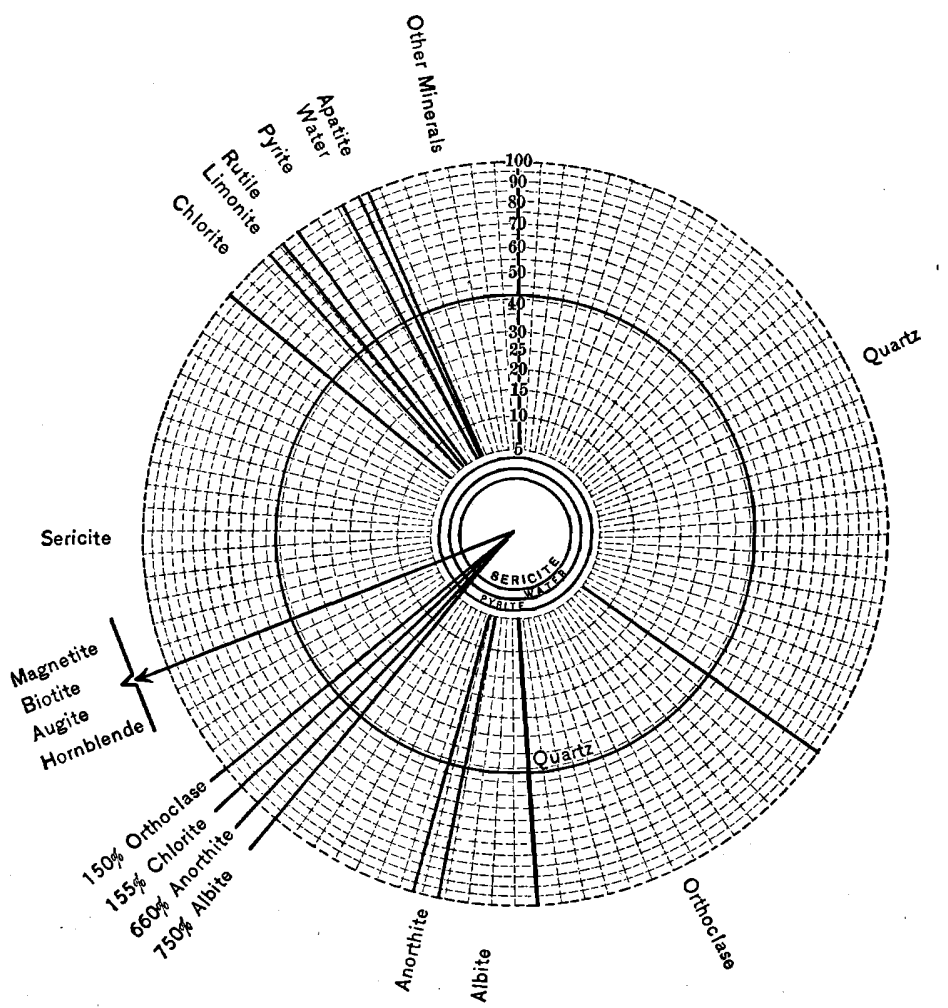

Fig. 34. Diagram VI. Diagram illustrating the mineralogical changes involved in the alteration of an average igneous rock by thermal solutions.

on an average less readily decomposed, and in the Cripple Creek and Tonopah districts, it occurs as a secondary mineral. Albite is known to occur as a secondary mineral resulting from hot solutions, but has not been found in the districts under discussion.

Chlorite occurs more or less abundantly, and is usually the 
most stable form assumed by magnesia under the action of hot solutions.

Titanite is altered to rutile, and pseudomorphs of pyrite after magnetite are common.

The minerals whose secondary development as a result of hot solutions is conspicuous are quartz, sericite and sulphides.

Conclusions on the Alteration of Acid Igneous Rocks by Hot Solutions.

The individual diagrams as well as the composites of the chemical and mineralogical changes of seventeen acid igneous rocks from the Pilbara, Tonopah, Clifton-Morenci, Bingham, Willow Creek and Cripple Creek districts, Diagrams V. and VI., justify the following conclusions on the alteration of acid igneous rocks in the cases under consideration:

I. The alteration of rocks by thermal solutions lacks rigid uniformity; that is the relative solubility or concentration of various constituents is variable.

2. Both introduction and removal of materials takes place. Certain substances are uniformly stable while others are persistently unstable.

The predominant chemical changes are a progressive increase

TABLE III.

Composition of Composites of Fresh and Altered Acid Igneous Rocks from Walls Adjacent to Ore-Bearing Fissures. The composite of the fresh rocks is an average of eight analyses, the composite of the altered of seventeen analyses from the Tonopah, Clifton, Bingham, Willow Creek, Pilbara and Cripple Creek districts.

\begin{tabular}{|c|c|c|c|c|c|c|c|c|}
\hline 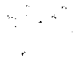 & & Fresh & Altered. & $\begin{array}{c}\text { Fresh } \\
\text { Altered. }\end{array}$ & & Fresh. & Altered. & $\begin{array}{c}\text { Fresh. } \\
\text { Altered. }\end{array}$ \\
\hline \multirow[t]{2}{*}{$\begin{array}{l}\mathrm{SiO}_{2} \\
\mathrm{Al}_{2} \mathrm{O}_{3} \\
\mathrm{Fe}_{2} \mathrm{O}_{3} \\
\mathrm{FeO}_{3} \\
\mathrm{MgO} \\
\mathrm{CaO} \\
\mathrm{Na}_{3} \mathrm{O} \\
\mathrm{K}_{2} \mathrm{O}\end{array}$} & " & $\begin{array}{r}61.73 \\
16.42 \\
1.73 \\
2.84 \\
2.16 \\
3.56 \\
4.28 \\
4.03\end{array}$ & $\begin{array}{r}66.40 \\
14.80 \\
1.67 \\
.92 \\
.94 \\
.90 \\
1.10 \\
4.76\end{array}$ & $\begin{array}{r}92 \\
\text { I I I } \\
\text { IO4 } \\
284 \\
230 \\
396 \\
402 \\
84\end{array}$ & $\begin{array}{l}\mathrm{H}_{2} \mathrm{O}- \\
\mathrm{H}_{2} \mathrm{O}+ \\
\mathrm{TiO}_{2} \\
\mathrm{P}_{2} \mathrm{O}_{5} \\
\mathrm{CO}_{2} \\
\mathrm{~S} \\
\mathrm{SO}_{3} \\
\mathrm{FeS}_{2}\end{array}$ & $\begin{array}{r}.44 \\
1.06 \\
.69 \\
.14 \\
.45\end{array}$ & $\begin{array}{r}1.15 \\
2.52 \\
.54 \\
.14\end{array}$ & $\begin{array}{r}38 \\
40 \\
126 \\
100\end{array}$ \\
\hline & & & & & $\mathrm{Fe}$ & $3.4^{\circ}$ & 2.95 & II4 \\
\hline
\end{tabular}


TABLE IV.

Mineral Analysis of the Average Fresh and Altered Acid Igneous Rocks from Walls Adjacent to Ore-Bearing Fissures. Source of the same as Table V.

\begin{tabular}{|c|c|c|c|c|c|c|c|}
\hline & Fresh. & Altered. & $\begin{array}{c}\text { Fresh } \\
\text { Altered. }\end{array}$ & & Fresh. & Altered. & $\begin{array}{l}\text { Fresh. } \\
\text { Altered. }\end{array}$ \\
\hline Quartz........ & 14.40 & 35.07 & $4 \mathrm{I}$ & Apatite..... & .48 & .28 & I7 I \\
\hline Orthoclase............. & 21.20 & 14.27 & 150 & Titanite ............ & .95 & & \\
\hline Albite................ & 32.22 & $4 \cdot 31$ & 750 & 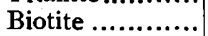 & 6.44 & & \\
\hline Anorthite............. & 8.00 & I.2I & 660 & Augite ................. & 2.59 & & \\
\hline Sericite................ & $3 \cdot 73$ & 31.86 & I. 17 & Hornblende ...... & 3.70 & & \\
\hline Chlorite............... & 3.70 & 2.40 & 155 & Pyrite............. & .08 & 2.29 & 3.50 \\
\hline Limonite.............. & & .67 & & Rutile.... & & .55 & \\
\hline Magnetite............ & 2.09 & & & Water.............. & .60 & .61 & 100 \\
\hline
\end{tabular}

Minerals entirely decomposed; magnetite, biotite, hornblende, augite and titanite.

in potash and silica, and a progressive elimination of soda, lime, magnesia, ferric oxide, ferrous oxide, iron and alumina. Of the constituents removed, soda is generally the most soluble. The solubility of the others follows in the order in which they are named, lime being by far the most soluble. Oxidation appears to increase ferric iron at first, but the general tendency is for the removal of both ferric and ferrous iron. Alumina is the most refractory of the substances removed, but generally passes out as soon as the bases necessary for the existence of basic-aluminium silicates are removed. Kaolinite is only exceptionally developed and it is a mooted question whether it ever is a normal product of thermal alterations or whether it is superimposed upon the latter by the agencies of weathering.

Hydration is at first important but necessarily diminishes after a certain elimination of bases has taken place.

Sulphides, especially pyrite, are introduced. Wherever their introduction is abundant, they tend to increase the mineral volume of the rock mass.

4. The predominant mineral changes are silicification, sericitization and the development of sulphides, especially pyrite.

In general chlorite is the most stable form assumed by magnesia and iron under the conditions, although there are some apparent exceptions. 
Orthoclase may be decomposed or it may occur as a secondary mineral. In general the former is the more important process.

Amphiboles, pyroxenes, magnetite, biotite and titanite are readily decomposed. Titanite alters to rutile, and magnetite changes in part at least to limonite and pyrite.

The lime-soda feldspars are always more or less decomposed depending upon the degree of alteration.

5. The net result of the alteration of acid igneous rocks by thermal solutions involves molecular simplification, and slight net increase in mineral density depending upon the introduction of heavy sulphides.

\section{THE ALTERATION OF ROCKS BY WEATHERING.}

The weathering of acid igneous rocks is given detailed attention in order to make a comparison with the chemical and mineralogical changes effected by hot solutions. Attention is also called to the weathering of basic igneous rocks to show the dependence of these changes upon the constitution of the rocks themselves. The weathering of individual specimens is not brought under discussion. The results of weathering are remarkably uniform and therefore it is more instructive to consider the chemical and mineralogical changes of composites made up from a number of analyses.

\section{METHOD OF OBTAINING AVERAGE COMPOSITIONS OF THE WEATHERED ROCKS.}

Average compositions of the fresh acid or basic igneous rocks may be found by direct summation, but this method is open to criticism when used for finding the average composition of weathered rocks, since the rates with which the various soluble constituents are lost vary with the degree of alteration. A true average composition of the weathered rocks is based on an average of the rates of loss.

A fairly satisfactory method of finding average compositions of weathered rocks on the basis suggested is by platting all the original compositions of the weathered rocks on one ordinate as shown for silica and alumina in Fig. 35 . 
Alumina is regarded as constant relatively in weathering and therefore its rate of increase is represented by parallel, ascending lines of convenient slope. The abscissæ of the ordinates on which the compositions of the weathered rocks are platted are therefore controlled by the increase in alumina, or the degree

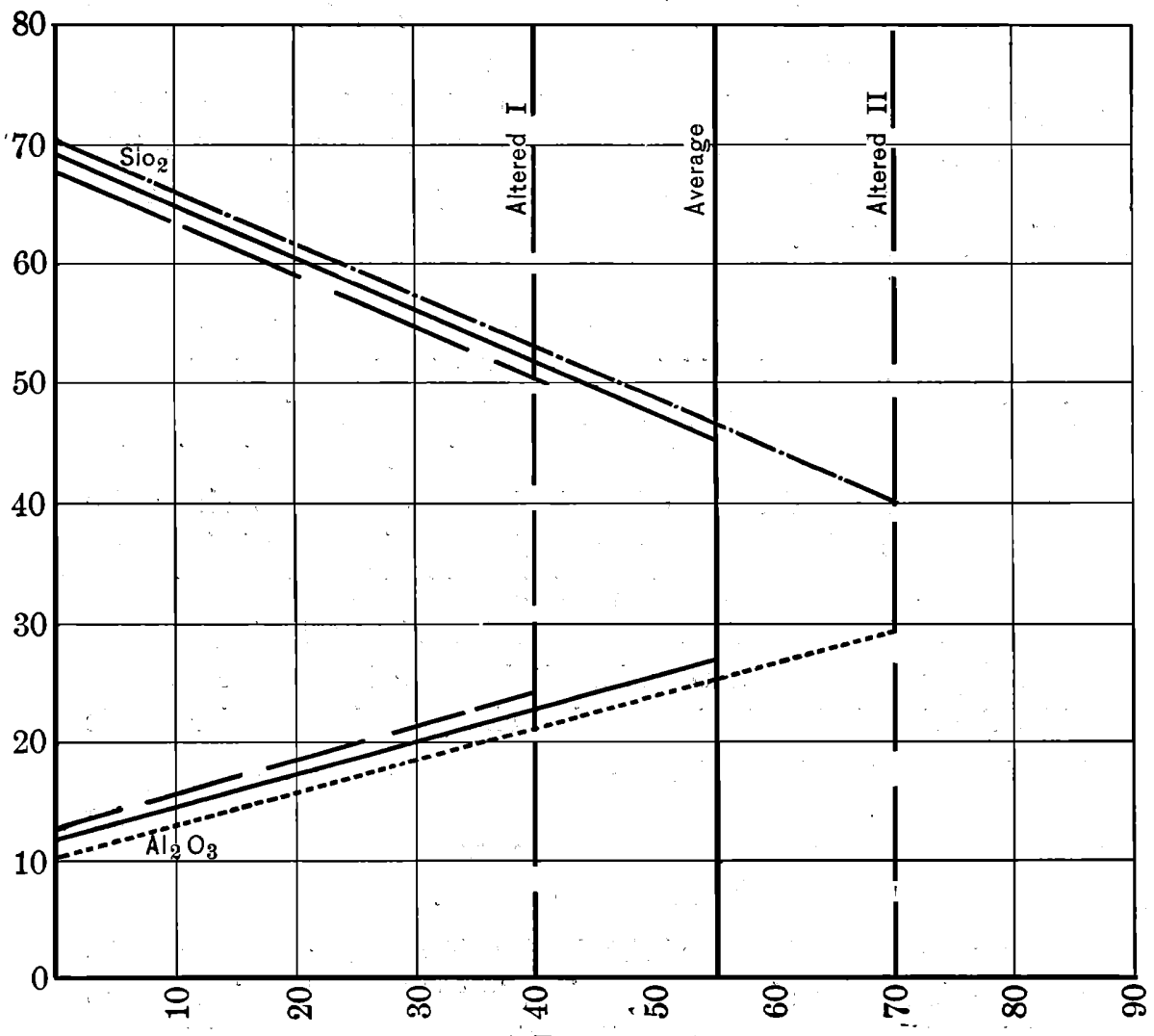

FIG. 35.

of alteration. The descending slopes of the lines connecting the soluble constituents of the fresh and weathered rocks, as shown for silica in Fig. I, represent the rates of loss of the constituents in the various stages of decay, and an average of the slopes of each constituent, as shown by the continuous lines in Fig. I, is an average rate of loss. When these average slopes 
are platted with an average of the original compositions, an average composition of the weathered rocks is obtained by finding the intercepts of the slopes on ordinates chosen with respect to the desired degree of alteration.

TABLE V.

Fresh Granitic Rocks Average of Eight Grorgia Granites. (Bull. 9a, Georgia Geological Survey, and one District of Columbia granite.) An intermediate stage of alteration is assumed.

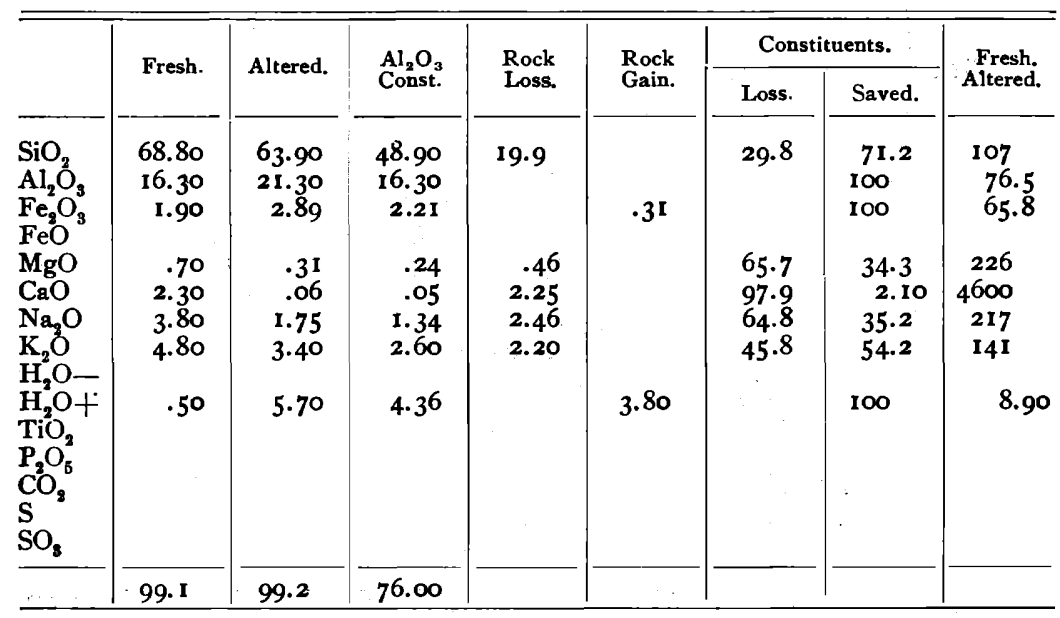

CHEMICAL CHANGES IN THE WEATHERING OF AN ACID IGNEOUS ROCK.

The original average acid igneous rock, Diagram VII., Table $V$., is composed of eight granites of Georgia, and one from the District of Columbia. Its moderately weathered product was found by the method of average slopes.

The chemical changes indicated by the diagrams hold for the individual rocks as well as for the composites. They consist in a loss of all constituents excepting alumina; ferric oxide and water. Alumina and ferric oxide remain about constant: Water is added:

The following table shows the ratio of the solubilities of the various oxides assuming alumina constant: 


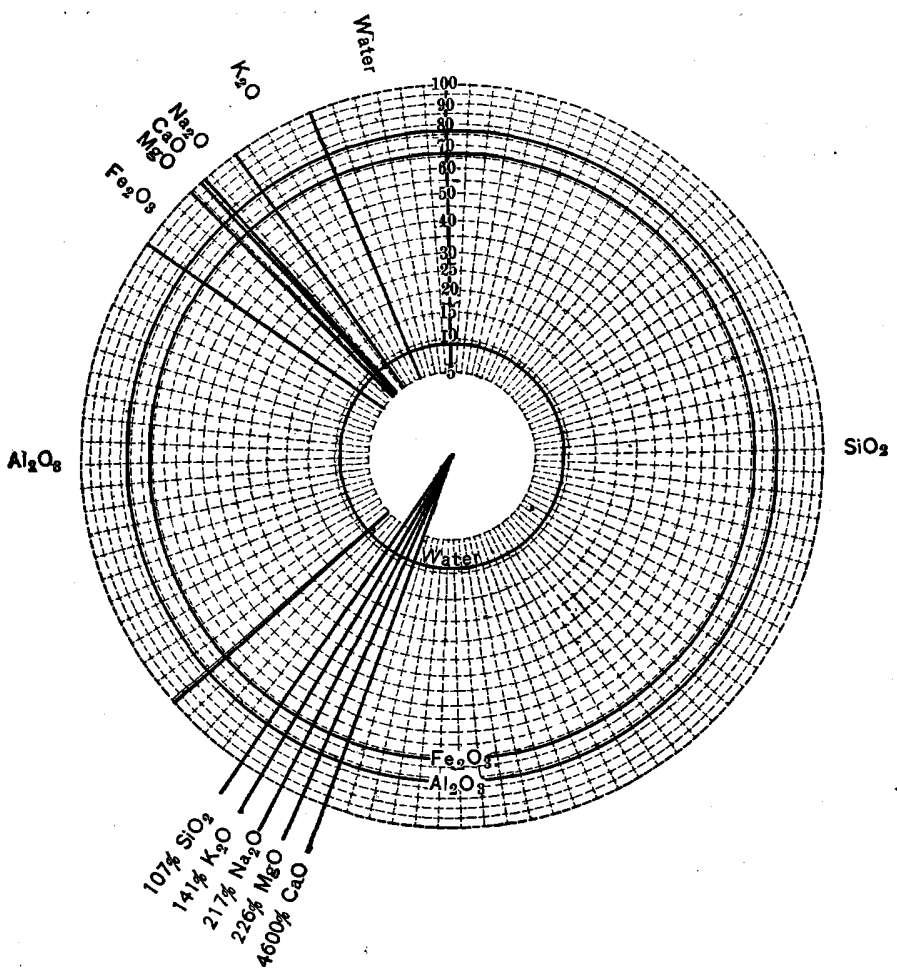

Fig. 36. Diagram VII. Diagram showing the chemical changes from an average acid igneous rock to a weathered equivalent.

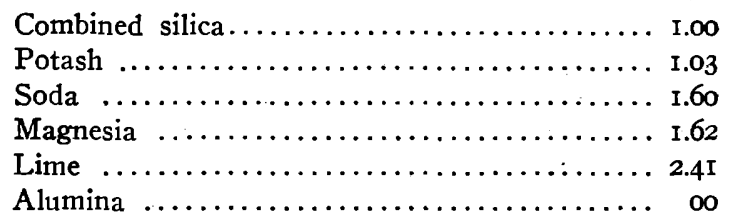

CHEMICAL CHANGES IN THE WEATHERING OF BASIC IGNEOUS ROCKS.

The chemical changes indicated by Table VI. of the basic igneous rocks hold for the individual rocks as well as for the composite. Competent students of metamorphism have found that alumina suffers practically no change in the weathering of rocks, so far as chemical processes are concerned. Assuming 
alumina constant, ferric oxide and water have gained. The increase in ferric iron comes from the oxidation of ferrous silicates. The complete decomposition of the latter results in a loss of iron. Taking alumina as unchanged the ratio of solubilities is as follows:

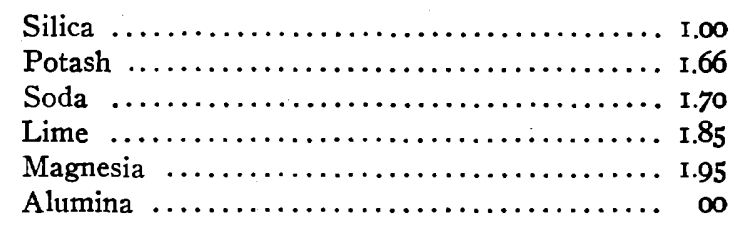

The order of solubility is the same as in the acid igneous rocks, excepting that in basic rocks high in magnesia, the latter is generally more soluble than lime.

TABLE VI.

Average of Five Fresh and Weathered Basic Rocks from Merrill's Rock Weathering, etc., viz., diabase from Spanish, Guiana; Medford, Mass.; basalt from Bohemia, Crouzet, France, diorite from Albemarle Co., Va.

\begin{tabular}{|c|c|c|c|c|c|c|c|c|}
\hline & Fresh. & Altered. & $\begin{array}{c}\text { Fresh } \\
\text { Altered. }\end{array}$ & $\begin{array}{l}\text { Altered. } \\
\mathrm{Al}_{2} \mathrm{O}_{3} \\
\text { Const. }\end{array}$ & Losses. & Gains. & $\begin{array}{l}\text { Per } \\
\text { Cent. } \\
\text { Saved. }\end{array}$ & $\begin{array}{l}\text { Per } \\
\text { Cent. } \\
\text { Lost. }\end{array}$ \\
\hline $\begin{array}{l}\mathrm{SiO}_{2} \\
\mathrm{Al}_{2} \mathrm{O}_{3} \\
\mathrm{Fe}_{2} \mathrm{O}_{3} \\
\mathrm{FeO} \mathrm{MgO} \\
\mathrm{CaO} \\
\mathrm{Na}_{2} \mathrm{O} \\
\mathrm{K}_{2} \mathrm{O} \\
\mathrm{H}_{2} \mathrm{O}- \\
\mathrm{H}_{2} \mathrm{O}+ \\
\mathrm{TiO}_{2} \\
\mathrm{P}_{2} \mathrm{O}_{5} \\
\mathrm{CO}_{2} \\
\mathrm{~S} \\
\mathrm{SO}_{3}\end{array}$ & $\begin{array}{r}47.00 \\
15.70 \\
4.78 \\
9.96 \\
6.36 \\
8.96 \\
2.77 \\
1.23 \\
\\
3.24\end{array}$ & $\begin{array}{r}42.50 \\
21.60 \\
17.00 \\
2.70 \\
4.20 \\
1.50 \\
.70 \\
9.80 \\
\\
100\end{array}$ & $\begin{array}{l}110 \\
72.6 \\
28.10 \\
235 \\
213 \\
187 \\
177 \\
34.1\end{array}$ & $\begin{array}{r}29.90 \\
15.70 \\
\text { I } 1.98 \\
\\
1.90 \\
2.96 \\
1.06 \\
.49 \\
6.80\end{array}$ & $\begin{array}{r}17.00 \\
\\
4.46 \\
6.00 \\
1.71 \\
74\end{array}$ & 3.56 & $\begin{array}{l}63.8 \\
100 \\
100 \\
\\
29.8 \\
33 \\
38.3 \\
39.8\end{array}$ & $\begin{array}{c}36.20 \\
100 \\
70.1 \\
67.0 \\
61.7 \\
60.2\end{array}$ \\
\hline $\mathrm{Fe}$ & I I. IO & 11.19 & 100 & 8.14 & 2.96 & & $73 \cdot 5^{\circ}$ & 26.5 \\
\hline
\end{tabular}

MINERALOGICAL CHANGES INVOLVED IN THE WEATHERING OF THE ACID AND BASIC IGNEOUS ROCKS.

Table VII. gives the mineral composition of an average crystalline rock computed from Clarke's analysis of an average 
igneous rock. It also gives the mineral composition of its completely weathered equivalent assuming all the materials to have remained in situ, and to have reached their most stable form under katamorphic conditions.

The end products of weathering are essentially quartz, kaolin, and the carbonates of lime and magnesia. Sodium and potassium occur as chlorides in the sea, in their final form as products of weathering. The iron reaches its most stable form as hydrated hematite or limonite.

Weathering results in the molecular simplification of minerals as is shown by the transformation of more or less complex silicates into simple oxides, carbonates and hydrates. It also involves slight net decrease in mineral density.

TABLE VII.

Mineralogical Composition of an Average Crystalline Rock, and its Complete Weathered Equivalent, Assuming all the Materials to have Remained in Srtu. From computations based on Clark's average crystalline rock analysis, U. S. Geol. Survey, Bull. 288, p. I8.

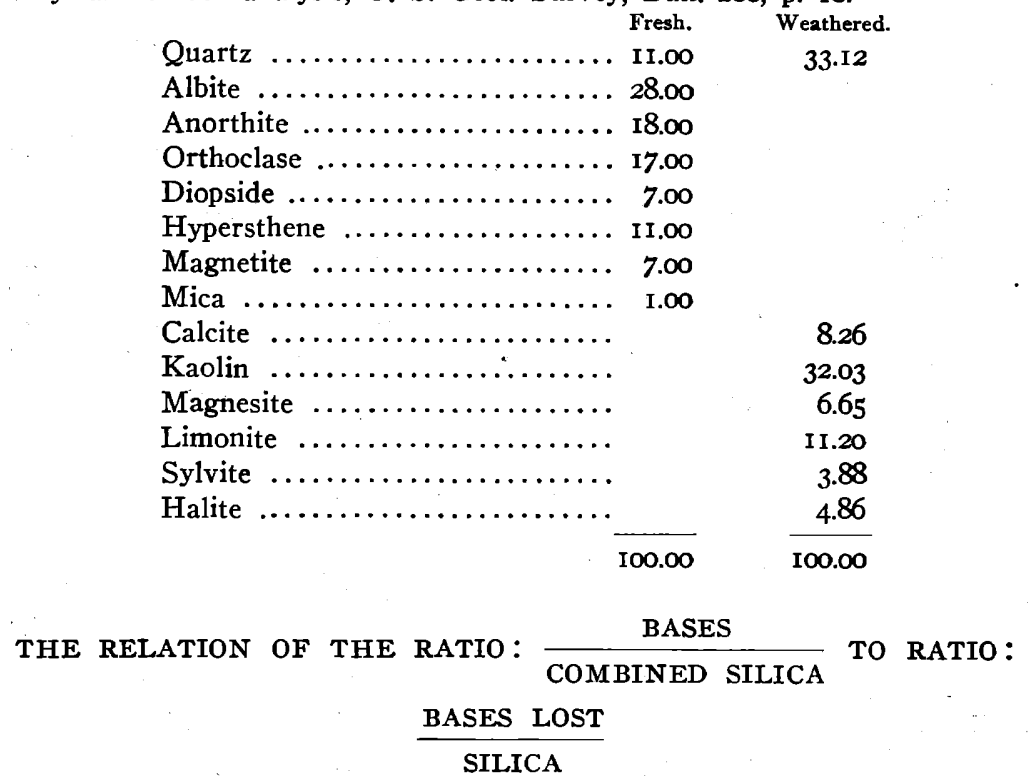

The ratio of the bases in the acid igneous rocks, including lime, soda, magnesia, potash and some ferrous iron to combined 
silica is $I I .6: 48.8$ or $I: 4.2$. The ratio of the loss of these bases to the loss of silica, as shown by Fig. 2 is $I: 2.7$.

In the basic igneous rocks the ratio of the bases magnesia, lime, soda, potash, some ferrous and ferric iron to the silica with which they are combined is $24: 47$ or $1: 1.95$. The ratio of their losses is I:I.og. The preceding ratios are based on

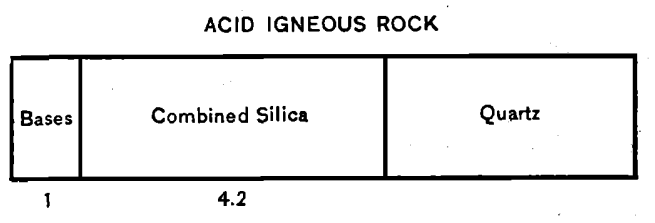

LOSSES FROM ACID IGNEOUS ROCK

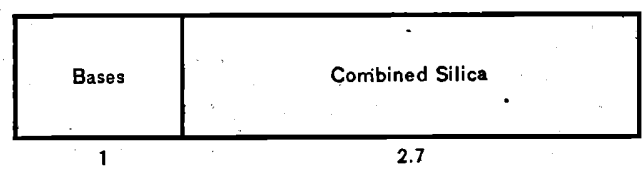

BASIC IGNEOUS ROCK

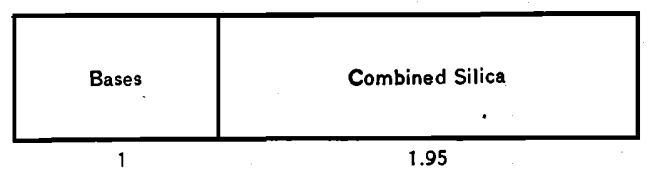

LOSSES FROM BASIC IGNEOUS ROCK

Fig. 37. Illustrating the ratios between combined silica and bases in the acid and basic igneous rocks and their losses as shown by the composites and the individual analyses.

computations made on the composites given in this article and on the individual analyses.

On comparison of the ratios with which bases and silica are combined in the acid and basic igneous rocks, to the ratio of their losses, it appears that the silica lost by solution on decomposition of a silicate is directly proportional to the ratio of 
combined silica to bases. In acid igneous rocks about twice as much silica is combined with a given weight of bases as in the basic igneous rocks. The loss of silica to the percentage of bases lost is about twice as great in the acid igneous rocks as in the basic. This relation between the ratio of combined silica to bases in the igneous rocks is interpreted as a sequence of the law of mass action. The bases in the acid igneous rocks which are combined with silica in the ratio of approximately $\mathrm{I}: 2$ adhere about twice as tenaciously to their silica as the bases of the acid igneous rocks, in which the ratio of bases to combined silica is about $I: 4$.

In the study of the redistribution of the elements from the original rocks to the sediments, the knowledge of this relation is a matter of paramount importance. The solutes resulting from rock decay are supposed to furnish the materials for the chemical precipitates, cementing materials, vein materials and salts of the sea. This raises the question whether the mass of chert, for instance, in the limestones bears any fixed relation to the lime content, depending upon the original constitution of the rocks from which the lime was derived. A similar relation should be looked for in the cherty iron formations.

\section{SUMMARY OF WEATHERING.}

I. The chemical and mineralogical changes effected by weathering are markedly uniform.

2. Weathering results in the loss of all constituents excepting water. Alumina and ferric iron are lost to such a slight extent that for purposes of comparison, they can be regarded as constant. Water receives considerable addition. The order in which the constituents are lost is lime, magnesia, soda, potash, silica, iron and alumina. In very basic rocks the rate of loss of magnesia may exceed that of lime.

3. The mineralogical changes involved in weathering of igneous rocks consists in the decomposition of the silicates into simple oxides, carbonates, hydrates and chlorides, which are essentially quartz, the carbonates of lime and magnesia, kaolin and limonite and the chlorides of soda and potash. These changes are ac- 
companied by molecular simplification and slight net decrease in mineral density.

4. In the weathering of igneous rocks, the proportion of bases to silica lost is determined by the ratio in which silica and bases are combined.

COMPARISON OF WEATHERING AND THERMAL ALTERATION.

This comparison relates to the specific alterations which have been here considered. The general conclusions as stated for weathering are believed to apply to all changes produced by weathering, allowing only minor modifications. To what extent the conclusions relating to the alteration of rocks by thermal solutions apply to all changes of this nature is uncertain. This comparison refers to the acid igneous rocks only.

I. The alteration of rocks by weathering is characteristically uniform, being based upon silicate ratios. Lack of uniformity is peculiar to the alteration of rocks by thermal solutions.

2. The loss of silica and bases in the weathering of rocks is controlled by the ratio in which silica and bases are combined. No such relation is observed in the alteration of rocks by hot solutions.

3. In weathering, solution dominates. With the exception of the addition of water, carbon dioxide and oxygen, no essential introduction of materials takes place. Thermal solutions alter rocks by addition and subtraction of materials.

4. Carbonation, hydration and oxidation are the dominant processes in weathering. They are generally subordinate in the changes affected by hot solutions. Silicification and sericitization stand out boldly as characteristic changes involved by the action of the latter.

5. The constituents removed by weathering are lime, magnesia, soda, potash, silica and ferrous oxide. In general soda is by far the most soluble constituent when alterations are caused by thermal solutions. Lime, magnesia, ferrous oxide and alumina follow in the order given. Alumina is nearly always removed when the bases necessary for the existence of basic aluminium silicates have been removed. It is inferred that the exceptions 
to this rule may be due to normal weathering superimposed upon changes caused by thermal solutions. Potash sulphides and silica are increased. Total iron is decreased. Hydration is important until the elimination of bases has progressed beyond a certain stage.

6. The characteristic minerals of weathering are oxides, carbonates, hydrates and chlorides, such as quartz, limonite, carbonates of lime and magnesia, kaolinite, and the chlorides of soda and potash. Their development involves molecular simplification and slight net loss in density. The minerals which are peculiar to thermal alterations are sericite, quartz, sulphides, sometimes secondary orthoclase, and to a subsidiary extent chlorite and other accessory minerals. Chlorite is generally the most stable form assumed by magnesia compounds under these conditions. The mineral development involves molecular simplification and usually a slight net gain in mineral density as a result of the introduction of sulphides. A tabulation of the changes involved in the alteration of acid igneous rocks by weathering and by hot solutions is given below.

Tabulation of the Changes Involved in the Weathering of Acid. Igneous Rocks AND their Alteration by Hot Solutions. Chemical Changes.

Weathering.

Oxidation important.

Carbonation important.

Hydration important.

Loss of all constituents excepting alumina, ferric oxide and water. Water is introduced.

General order of solubility: Lime, General order of solubility: Soda, magnesia, soda, potash, silica.
Hydration subordinate.

Loss of soda, lime, magnesia, ferric oxide, ferrous oxide, iron and alumina. Concentration or introduction of potash, silica and sulphides.

lime, magnesia, ferric oxide, ferrous oxide and alumina.

\section{Mineralogical Changes.}

Development of oxides, carbonates, Development of oxides, carbonates, and hydrates important. etc., subordinate.

Characteristic minerals: Quartz, Characteristic minerals: Quartz, kaolinite, calcite and limonite. sericite, sulphides, chlorite, occasionally adularia (Oxides, carbonates, etc., accessory.) 
Decomposition of all original min- Decomposition of all original minerals not in the list of secondary erals not in the list of secondary minerals. minerals. Amphiboles, pyroxenes, magnetite and biotite readily decomposed. Feldspars somewhat more persistent.

Slight net increase in mineral vol- More or less net decrease in mineral ume. volume, depending on the introduction of sulphides.

Molecular simplification. Molecular simplification.

So far as thermal alterations are quantitatively known, they differ characteristically from those of weathering. These differences may be satisfactorily measured against the fairly wellknown weathering processes and a better idea gained thereby of the nature of the thermal processes.

The author is indebted to $\mathrm{C}$. $\mathrm{K}$. Leith for suggestions and criticism. 